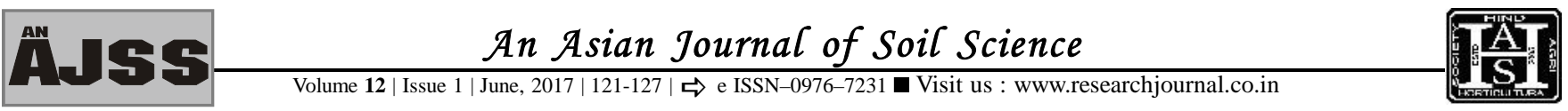

\title{
Soil health of soils in Aurangabad district (Maharashtra), India
}

\section{S.S. AJGAONKAR AND S. S. PATIL}

Received : 10.03.2017; Revised : 26.04.2017; Accepted : 08.05.2017

\section{MEMBERS OF RESEARCH FORUM:}

Corresponding author :

S.S. AJGAONKAR, Department of

Environmental Science, Dr.

Babasaheb Ambedkar Marathwada

University, AURANGABAD (M.S.)

INDIA

Email: suhas.ajgaonkar@gmail.com

Co-authors :

S.S. PATIL, Department of Environmental Science, Dr.

Babasaheb Ambedkar Marathwada

University, AURANGABAD (M.S.)

INDIA

Email: sushshrey@ rediffmail.com

\section{Summary}

Improper agricultural practices, intensive farming with monoculture cropping pattern are responsible for deterioration of soil quality. To overcome the adverse effect of current cultivation practices, sustainable agricultural practices should be adopted. The evaluation of soil health status of Aurangabad district has been carried out with 240 surface soil samples from 12 villages of 3 blocks. The soil was analyzed for various soil fertility parameters such as $\mathrm{pH}, \mathrm{EC}$, organic matter and availability of NPK. The soils of Aurangabad district are moderately alkaline in nature with a mean value of $\mathrm{pH} 7.89$. The soils are good soil with $\mathrm{EC}$ ranging from 0.2 to $1.70 \mathrm{dS} / \mathrm{m}$ with mean of $0.74 \mathrm{dS} / \mathrm{m}$ in Aurangabad district. The soils of Sillod block, 27.5 per cent, have to face seed emergence problem due to higher EC. The organic carbon content of soils of Aurangabad is low, mean value being 0.39 per cent. The half of the soil of Aurangabad district is having low organic carbon less than 0.40 per cent. The available nitrogen of soils of Aurangabad is low, with mean of $158.39 \mathrm{~kg} / \mathrm{ha}$. It is remarkably very low in Sillod and Aurangabad blocks. Part of Aurangabad, 52.08 per cent is very low in available phosphorus content, whereas 38.75 per cent soils have low available phosphorus content. They are very rich in potassium with a mean value of $443.60 \mathrm{~kg} / \mathrm{ha}$. There is dire need of improvement in soil organic carbon by using organic manures including intercropping, mixed cropping and adopting integrated nutrient management programme.

Key words : Crop, Fertilizers, Farmland, Macronutrients, Minerals

How to cite this article : Ajgaonkar, S.S. and Patil, S. S. (2017). Soil health of soils in Aurangabad district (Maharashtra), India. Asian J. Soil Sci., 12 (1) : 121-127 : DOI : 10.15740/HAS/AJSS/12.1/121127. 